\title{
Can Integrated Water Resources Management Increase Adaptive Capacity to Climate Change Adaptation? A Critical Review
}

\author{
Animesh K. Gain ${ }^{1}$, Josselin J. Rouillard ${ }^{2}$, David Benson ${ }^{3}$ \\ ${ }^{1}$ Department of Economics, Ca' Foscari University of Venice, Venice, Italy \\ ${ }^{2}$ School of Environmental and Social Sciences, University of Dundee, Dundee, UK \\ ${ }^{3}$ The Tyndall Centre for Climate Change Research, University of East Anglia, Norwich, UK \\ Email: animesh.gain@gmail.com, josselinrouillard@gmail.com,d.benson@uea.ac.uk \\ Received February 2, 2013; revised March 5, 2013; accepted March 19, 2013
}

Copyright (C) 2013 Animesh K. Gain et al. This is an open access article distributed under the Creative Commons Attribution License, which permits unrestricted use, distribution, and reproduction in any medium, provided the original work is properly cited.

\begin{abstract}
Integrated Water Resources Management (IWRM) is now a global paradigm. While conceptions of IWRM principles vary between contexts, it primarily aims to ensure more coordinated management between different aspects of water issues such as water quality, land management and habitat protection. However, one increasingly significant cross-cutting management issue is climate change adaptation which presents multiple problems for IWRM approaches. This paper therefore seeks to gauge the extent to which IWRM principles can, and indeed are, enhancing the adaptive capacity of water management through reducing vulnerability and increasing the resilience of social-ecological systems. A review of research into vulnerability and resilience to date suggests that IWRM has significant potential for supporting some of the key determinants of adaptive capacity. However, despite IWRM being promoted as an attractive approach, our assessment argues that IWRM, as currently practiced, cannot readily enhance flexibility and adaptability, which is required for climate change adaptation. Normative recommendations for future policy are then provided.
\end{abstract}

Keywords: IWRM; Adaptive Capacity; Resilience; Vulnerability; Climate Change Adaptation

\section{Introduction}

Water resources systems (WRS) are in complex interaction with both social and ecological sub-systems, which make decision making difficult. Therefore, the traditional fragmented approach of water management has to be replaced by more holistic system view approaches. Integrated Water Resources Management (IWRM) is the dominating policy paradigm in water resources management, and is currently being widely applied internationally [1]. IWRM is an umbrella concept encompassing multiple principles which, overall, aim to result in more holistic and coordinated management between the different aspects of WRS. Several reasons may explain why IWRM is seen by many scholars and practitioners as the most appropriate overall strategy for managing water resources [2]: 1) it is comprehensive and holistic approach that takes into account all types resources and sectors; 2) IWRM makes the links between the livelihood of the catchment and resource perspective; 3) it incorporates the elements of good governance [3].
Along with other development activities (e.g., population pressure, land use change, economic development), anthropogenic climate change is increasing pressure on WRS [1]. Given these multiple impacts on WRS, adaptation to climate change has become a source of great attention and IWRM has been advocated as a means of climate change adaptation [4].

This paper aims to contribute to this growing body of work by examining how IWRM, as the current paradigm in water resources management, contributes to increasing the "adaptive capacity" of WRS to climate change. Previous attempts at doing so have usually focused on how adaptive management can inform IWRM [5], and the tensions with implementing Integrated and Adaptive Water Resource Management (IAWRM) e.g., Engle et al. [6]. Another line of work has evaluated the broader institutional prescriptions of Adaptive Water Management [7]. These studies have nevertheless often been carried out with little conceptual understanding of "adaptive capacity". Recent developments in research on the concept of "adaptive capacity" [8,9] now better define the term 
and its complex, multiple dimensions. The objective of this study is to use these new insights to examine how, and to what extent, IWRM principles and guidelines facilitate adaptive capacity to climate change impacts.

The remainder of this paper is organized as follows. In Section 2, we discuss the conceptual interpretations of IWRM. Indeed, the single greatest barrier to effective comparative analysis of social processes is conceptual imprecision. For Sartori [10] concepts sit on a "ladder of abstraction", whereby tightly defined concepts allow effective comparative analysis when moving between contexts worldwide. As we move up the analytical "ladder" by expanding the conceptual range in order to encompass more and more in explanatory terms, "concept stretching" can occur meaning "gains in extensional coverage tend to be matched by losses in connotative precision" (ibid.: 1035). It remains critical, therefore, when discussing the influence of widely applied (and seemingly familiar) concepts such as IWRM to define their main features as precisely as possible. This situation presents something of a problem as the current literature tends to -rather uncritically - define IWRM using multiple interpretations, i.e. "stretching" is evident [11]. Our analysis therefore initially examines the origins of IWRM and its diffusion worldwide as an environmental management technique looking at its different geo-political variants. We then review key arguments on the nature of IWRM in order to provide a more coherent definition to guide our analysis. In Section 3, the key dimensions of adaptive capacity are outlined. Similar issues of "conceptual imprecision" have hindered studies of adaptive capacity. We therefore briefly discuss the origin and development of the concept, highlighting the two main traditions, i.e. vulnerability and resilience, underpinning past research. We present a list of key determinants of the adaptive capacity of social-ecological systems which we will use to evaluate IWRM. Theoretical linkages, and empirical relationships as identified in the existing literature, between IWRM principles and determinants of adaptive capacity are then discussed in Section 4. The paper concludes with lessons learned for policymakers and practitioners.

\section{IWRM-Origins, Interpretations and Conceptual Reframing}

\subsection{Looking Back: IWRM in Historical Perspective}

IWRM has its roots in attempts to integrate different aspects of water management at river basin scales in Europe, North America, Australia and other countries. In many of these contexts, recognizable forms of integrated water management based on river basins have been evident throughout the 20th Century [12]. For example,
Gerlak [13] and Sabatier et al. [14] show how US watershed management developed in several phases in the period after the 1920s. One significant early example of an integrated approach is the Tennessee Valley Authority 1933 (TVA); essentially a technocratic, agency-led approach to planning at a regional river basin scale [15]. Meanwhile, in Britain drainage districts became based on individual catchments as early as 1930 and, under the 1945 Water Act, the river basin was then established as the fundamental unit for managing fishing and pollution nationally [16]. France also was an early exponent of river basin management with the creation of the Compagnie Nationale du Rhône in 1921, although its principal function was generating hydroelectric power [12]. In parallel, managing water resources at the local catchment scale in Australia dates back to the late 1900s, while regional natural resource planning was evident in several Australian states in the 1930s and 1940s [17]. The success of the TVA also led to the export of this model to developing countries as large-scale water engineering projects became a means to drive national development strategies. As Molle [12] describes, "TVA-like river-basin development plans mushroomed all over the world", with schemes in Asia, Africa and South America. For several decades, Integrated River Basin Development, where water resources were exclusively developed for human benefit, became the global norm (ibid.).

By the 1970s, however, Molle [12] notes that in many countries there was "a certain demise and loss of appeal of the river-basin concept, especially as a unit for development". As he suggests, the need to remediate chronic water pollution problems led to a concentration on regulating point source emissions via "state-centred, expert-/ agency driven and managerial" responses (ibid.): a factor evident in the US Clean Water Act amendments (1972) [14] and early EU water directives [18]. Some attempts were made in the UK to rationalise water management functions in regional water authorities, although the outcomes in this case were less than "integrated" [16]. But worldwide during the 1970s water management was typically characterised by an engineering paradigm based on project-led, sub-sectoral solutions and a "predict and provide" approach to water services [19].

By the end of the 1980s, it was apparent that these measures were not addressing diffuse pollution and complex management problems, and the rationale re-emerged for more integrated approaches at the river basin scale. For example, Sabatier et al. [14] note that more locally collaborative watershed management in the US emerged in this period from a combination of dissatisfaction with federal-state legislation, amendments to the Clean Water Act and as a reaction to the litigious nature of water management. On a global scale, Biswas [20] describes how water professionals "began to appreciate that the 
water problems had become multi-dimensional, multisectoral and multi-regional" necessitating a "new paradigm". The response in the early 1990s was river basin planning and management in the form of a new conceptIWRM, although as Biswas [20] reflects, it was effectively "rediscovered" by water practitioners. The critical difference with earlier approaches, however, was the emphasis on environmental protection, stakeholder participation, equity and efficiency, each reflecting the discourse of sustainable development that was prevalent in the period after the publication of the Brundtland Report [21]. Integrated water resources management then became codified in 1992 via international norms such as the Dublin Principles of the International Conference on Water and the Environment and Rio UNCED Agenda 21. These norms then underpinned the global expansion of IWRM as a management concept in the late 1990s through their promotion by multi-lateral organisations such as the World Bank, the World Water Partnership (WWP) and the UN's Global Water Partnership (GWP) (see $[12,20])$. The latter two organizations have been particularly instrumental, with the WWP focusing more on policy transfer and the GWP on implementation of operational principles [19].

Since 2000, there has been a further expansion in IWRM type approaches worldwide. At the World Water Forum in The Hague (2000), 113 had countries adopted IWRM principles [19]. Further international endorsement came in 2000 when the UN adopted IWRM as part of its Millenium Development Goals [22]. In Europe, managing water resources at the river basin scale was then compelled by the EU Water Framework Directive 2000 [23]. The Directive introduces river basin management planning (RBMP) within designated river basin districts (RBDs), along with specific institutions to implement plan processes, although some have noted differences between the Directive and IWRM principles [24]. Other recognisable variants include watershed management in the USA (for example, Sabatier et al. [14]), integrated catchment management/natural resource management in Australia [17] and river basin planning and management in Canada [25]. However, it is in non-Western countries that the expansion of IWRM type approaches has been most marked, with forms evident in inter alia South Africa [26], Mongolia [27], Israel [28], Malawi [29], Tanzania [30] and Central Asia and the Caucasus [31].

\subsection{Conceptual Dis(order): Interpreting IWRM}

This global diffusion of practice has resulted in not only multiple interpretations of IWRM but also conceptual confusion. Although the GWP definition has attained some acceptance worldwide amongst scholars and practitioners (see for example, [22]), there is variance in con- ceptualisation of IWRM (for example, [32]). Biswas [20] sums up this conundrum by arguing that an assessment of different publications on IWRM "indicates that not only no one has a clear idea as to what exactly this concept means in operational terms, but also... views of it in terms of what it actually means and involves, vary very widely". To prove this point, he lists no less than 41 different objectives that proponents have ascribed to IWRM. Biswas [20] suggests that this conceptual malleability has contributed to the global success of IWRM since it legitimises a range of divergent but similar practices under this umbrella term. But as Fritsch and Benson [11] argue, this "all things to everyone" opaqueness also makes coherent analysis of IWRM problematic.

A brief overview of the IWRM literature would tend to confirm this observation. The GWP defines IWRM as:

"A process which promotes the coordinated development and management of water, land and related resources in order to maximise economic and social welfare in an equitable manner without compromising the sustainability of vital ecosystems and the environment" [33].

Here, IWRM is a process involving managing multiple resources in an equitable and environmentally sustainable way. But others adopt slightly differing definitions, with Ballweber [34], for example, suggesting "IWRM is blending or integrating actions and objectives favored by different players to achieve the best total result within a river basin or watershed". Therefore, this definition emphasises a participatory aspect in the attainment of ecological and societal goals. Some scholars, however, have identified IWRM more with specific scales [25], institutions such as river boards [30], poverty reduction [29], social learning [35] or even adaptive management [6,36]. Meanwhile, Savenije and Van der Zaag [19] in their conceptual review of IWRM define it in terms of four dimensions: water resources; water users; spatial scales; and temporal scales. The overall impression given is that there is an evident lack of an agreed definition of IWRM.

\subsection{Conceptual Reframing: Defining IWRM}

As Sartori [10] would no doubt note, significant conceptual stretching is therefore evident in the literature, making effective analysis of IWRM problematic. While Biswas [20] criticises the IWRM concept for its vagueness and expansive nature, he does not offer a coherent alternative to conceptualisation. A need therefore exists to reorder IWRM into a more consistent analytical framework in order to guide investigations. While we do not expect all scholars to accept our definition, nonetheless by drawing out the key features of IWRM, we can therefore stimulate a debate over areas of (dis)agreement.

So what are the essential features of IWRM? Firstly, and most obviously, it should involve an integrated ap- 
proach to water management, although "integration" warrants some pinning down. Principle 1 of the Dublin agreement on IWRM originally identified that:

"[W]ater is needed for different purposes, functions and services, therefore, water management should be integrated and take account of both demand for and threat to this resource" [37].

In response, the Global Water Partnership argues that IWRM should integrate "land and water, upstream and downstream, groundwater, surface water, and coastal resources" [33]. Consequently, the vast majority of IWRM type approaches implemented globally do prioritise multiple uses and different resources. For example, while the EU Water Framework Directive (WFD) focuses primarily on one specific aspect of water management, in this case the "good ecological status" of surface water resources, it also integrates groundwater protection and, from 2015 onwards, climate adaptation [11]. Australian approaches meanwhile tend to be more holistic in the way that water protection is integrated with measures to prevent inter alia soil degradation, salinisation and biodiversity loss (for example, [17]).

Secondly, IWRM is generally predicated on a specific scale, i.e. the river basin or catchment. The original Dublin Principles for IWRM [37] state that "[e]ffective management links land and water uses across the whole of a catchment area or groundwater aquifer". This central principle now underpins the discourse of IWRM worldwide. The Global Water Partnership thus refers to "managing water at the basin or watershed" as one of its key IWRM components [33]. Consequently, water management in the EU under the WFD occurs within a network of 110 river basin districts (RBDs), some such as the Danube spanning multiple Member States and even non-EU countries [23]. Mitchell [25] also describes how Canadian IWRM approaches involved four interlocking scales: watershed, sub-watershed, tributary, and site. However, we should be conscious of precisely defining the scale of management since this can, and does, vary according to context meaning cross-national comparison of IWRM should be approached with caution.

Thirdly, IWRM inevitably involves questions of governance. Although a "notoriously slippery" concept [38], governance typically equates to "the patterns that emerge from the governing activities of diverse actors [primarily governments] that can be observed in what is deemed acceptable norms of behaviour, and divergent institutional forms" [39]. One important metric is policy instruments, including regulations, market based instruments (MBIs) and also institutional forms [40]. With regards IWRM, the establishment of policy by governments is manifestly critical to governing water resources in an integrated manner, with examples including "the polluter-pays principle, water quality norms and stan- dards, and market-based regulatory mechanisms" [33]. That said, the global geography of IWRM governance is somewhat uneven, with inter alia: a regulatory model (the WFD) in the EU [18]; state level policy/regulation and federal funding in Australia (The Natural Heritage Trust/Caring for Our Country [41]), and a mixture of top-down regulatory and funding mechanisms and bottom-up watershed collaboratives in the USA [23].

Fourthly, another feature related to governance in IWRM is the participation of multiple stakeholders, including women and other water users, in managing water resources. The Dublin Principles were framed during the era of the UNCED Rio conference where the concept of sustainable development had specifically identified the role of public participation in environmental decisionmaking [23]. Consequently, Dublin Principles 2 and 3 specify that water management should involve "users, planners and policy-makers at all levels" and women, all play "a central part in the provision, management and safeguarding of water" [37]. Thus intersectoral, multistakeholder or participatory approaches are a significant part of conceptions of IWRM, for example, Mostert et al. [35] examine social learning amongst stakeholders between 10 different river basin organizations. The WFD also mandates public participation in river basin management planning through legal requirements embedded in Article 14.

Finally, this focus on multiple stakeholders in turn raises questions of equitable access and efficiency through demand management. The Dublin Principles originally stated that IWRM "is based on the equitable and efficient management and sustainable use of water" [37]. Thus, this principle has become incorporated into IWRM worldwide, with the GWP, for example, promoting “equitable access" via measures such as "support for effective water users" associations, involvement of marginalized groups, and consideration of gender issues [33]. The GWP also refers to the need to manage demand efficiently through specific interventions and optimize supply through proper assessment of resources, analysis of water balances, introducing wastewater recycling and evaluating environmental effects of water production (ibid.).

In terms of a definition, we might therefore argue that IWRM - in its contemporary form - is an integrated form of sustainably managing water and associated resources at the river basin scale involving specific governance forms that guarantee multi-stakeholder participation, equitable access and efficient use of water resources. The critical question, in terms of this paper, is therefore how well these dimensions of IWRM help ensure adaptive capacity to climate change: a feature discussed in the following sections. 


\section{Adaptive Capacity at the Crossroads of Vulnerability and Resilience Research}

\subsection{Defining Adaptive Capacity}

As for IWRM, defining adaptive capacity is a challenge because the concept is used in different research traditions. One such tradition is embedded in hazard-risk research and climate change adaptation, and was adopted by the IPCC in its $3^{\text {rd }}$ Assessment Report [42]. There, adaptive capacity is defined as the ability of a natural and social system to respond successfully to climate variability and change, and its measurement is mainly part of evaluations of the vulnerability of specific populations to the impacts of climate change. Vulnerability assessment typically involves the following: characterisation of the stress itself (e.g. rainfall for flooding), the biophysical factors (e.g. run-off, river geomorphology, soil conditions), exposure of the population (e.g. urban land use) and its susceptibility to be injured (e.g. level of education, income, health, gender, age) [8]. Adaptive capacity is measured via a set of observed properties of a system, in particular the availability of resources, technologies, knowledge/skills and infrastructures, as well as the characteristics of existing institutions (e.g. political system, entitlement rules) [42-44].

Here, two types of assessments can be distinguished $[8,45]$. One group may build an aggregate value of vulnerability so as to direct adaptation efforts to those areas with the highest vulnerability and lowest adaptive capacity. Adaptive capacity increases with the fair distribution of assets (e.g. economic and natural resources, technologies, skills, infrastructure) and equitable institutions (e.g. access to health care, education). These assessments tend to be based on static characteristics of the natural and social systems studied, and little attention is given to the conditions that can alter adaptive capacity in decisionmaking processes. Less common, the second group of assessments aims to evaluate the practical barriers and opportunities for implementing adaptation. Potential adaptation measures are identified, and compared for example via typical decision-making tools (e.g. cost-benefit analysis, cost-effectiveness). The processes and drivers underpinning the exposure and sensitivity of a population, and the adoption of adaptation measures are empirically assessed. Overall, this line of work better assesses economic, political and institutional factors modulating adaptive capacity.

\subsection{Vulnerability and Resilience}

Adaptive capacity is not only embedded in vulnerability studies, but is also examined in work based on resilience theory $[8,9]$. There, adaptive capacity is the ability of social actors to maintain or "steer" social-ecological systems into "desirable" stable states $[46,47]$. Desirability is socially constructed and negotiated, and may represent in some cases status-quo or, when untenable, a new state $[8,48,49]$. Assessments of adaptive capacity typically focus on the complex interactions, thresholds and feedbacks between natural and social systems following a shock or a crisis $[8,9,49]$. Determinants of adaptive capacity are empirically derived from observations of local natural resource management, and then used deductively to inform the analysis of other local case-studies. Here, we highlight three main dimensions.

First, attention is usually given to features that enable to learn from crisis and live with uncertainty and change [50]. Adaptive management cycles and the use of experimentation for example typically introduce an element of regular review and testing in decision-making processes and reinforce a culture of learning and change [7]. The second dimension is the existence of quasi-autonomous decision-making units operating at multiple spatial scales [7,46,51]. Thereby, social actors may have more flexibility to respond individually to specific issues. Higher, more centralised governance remains important because it helps coordinate action across social boundaries (e.g. catchments). A balance must be sought so as to support self-organising capacities, while ensuring synergistic interventions and avoiding conflicting ones between scales. The third dimension is the existence of participative processes $[47,48,52]$. They should enable exchange between social actors in order to create new relationships, beliefs, values and norms. Stronger forms of participative processes are thought more successful, in particular those that encourage the sharing of resources and power over decision-making. Weaker forms still help create new forms of collaboration which are better able than centralised bureaucracies to respond to new forms of social-ecological change and crisis.

We observe that the vulnerability and resilience approaches provide complementary information on the determinants of adaptive capacity, although little cross-fertilisation and combined assessments are yet available. Based on insights from the above discussion, we identify the five following determinants:

- A manageable natural and social system with few foreseeable thresholds and surprises;

- Adequate supply of resources, technologies, infrastructure, knowledge and skills that enables social actors to respond to evolving circumstances;

- An effective innovation and capacity-building system based on adaptive cycles and experimentation of local and scientific knowledge;

- A flexible decision-making system that enables local self-determination, while ensuring synergistic interventions and avoiding conflicting ones between scales;

- Accessible participatory mechanisms that support fair 
exchange between social actors and encourage the sharing of resources and power.

\section{Mapping IWRM against Determinants of Adaptive Capacity}

This section assesses how IWRM principles theoretically map against determinants of adaptive capacity (Table 1), as well as the extent to which this has been examined empirically in past studies. Only four principles of adaptive capacity are considered. The first principle on "a manageable natural and social system" is more dependent on the characteristics of the social-ecological system being studied than on the principles of good management and governance that IWRM aims to implement. The section is structured around the five principles of IWRM identified in Section 2.

\subsection{Integrated Management}

IWRM underpins an interdisciplinary approach to water resources management, linking social and economic development with protection of natural ecosystems. This holistic management recognises that water is required for many different purposes, functions and services and therefore, it aims to ensure optimum management. Integrated management commonly use the "policy cycle", which is based on regular reviews of strategies in order to learn from past implementation and adjust policy goals and instruments accordingly. This dimension of IWRM has strong parallels with the adaptive cycles in adaptive management [5]. Practicing integrated management therefore can help better account for the multiple dimensions of WRS, and consider possible interacting dynamics, thresholds and surprises. IWRM has nevertheless also leads to path dependency [53], often because of conflicting interests, views and understandings. IWRM requires coordination between stakeholders and government agencies, ideally supported by partnerships and participatory mechanisms that support fair exchange between social actors [54].

The objective of reaching optimum management in
IWRM (e.g. optimum supply of water across sectors) is not necessarily the best objective to increase adaptive capacity. This is because diversity is an important component of resilient social-ecological systems [46].

\subsection{Practicing River Basin or Watershed Scale Management}

River basins appear to be well-bounded "natural" boundaries, delineation by hydrological borders [55]. IWRM promotes river basins as logical planning units [56], for the purpose of water resource management, flood management, and water quality management. The main purported benefit of river basin management is that supply of resources can be made more efficiently and effectively $[57,58]$. Because river basins are hydrologically coherent physical boundaries, they are well fitted to support climate change adaptation. However, river basins commonly cross political, administrative and social borders. The mismatch between hydrological and sociopolitical borders and scales has proved to create important barriers to IWRM implementation [59,60]. The strict focus on river basins in IWRM is not coherent with the idea that decision-making should focus on local selfdetermination to enable adaptive capacity. IWRM also does not inform on how to ensure synergies between scales, a key requirement for adaptive capacity.

\subsection{Establishing Water Governance or Policy}

The most important features of good governance are often said to be accountability, transparency, participatory processes and decentralized decision-making [61]. Within IWRM, there has been a global paradigm shift away from traditional command and control to more decentralized and democratic water governance, which decision makers have perceived as a more appropriate model for adequate supply of resources through sustainable water management [6]. The proliferation of IWRM experiments around the world has led to a wide variety of institutional arrangements in water resource management [62]. For example, water governance in Singapore has

Table 1. Linkages between IWRM and adaptive capacity.

\begin{tabular}{|c|c|c|c|c|}
\hline \multirow[b]{2}{*}{ Dimensions of IWRM } & \multicolumn{4}{|c|}{ Determinants of adaptive capacity $^{\mathrm{a}}$} \\
\hline & Supply of resources & Adaptive cycle & Flexible decision making & $\begin{array}{c}\text { Accessible participatory } \\
\text { mechanism }\end{array}$ \\
\hline Integrated management & ++ & 0 & $+/-$ & ++ \\
\hline River basin as spatial scale & ++ & 0 & -- & + \\
\hline Water governance/policy & ++ & $+/-$ & $+/-$ & ++ \\
\hline Multi-stakeholder approach & ++ & ++ & $+/-$ & ++ \\
\hline Equity in resource access & ++ & 0 & 0 & ++ \\
\hline Demand management & ++ & 0 & 0 & ++ \\
\hline
\end{tabular}

a ++ positive effect; -- negative effect; 0 no effect; + /- positive or negative effect (case dependent). 
implemented a decentralized system with public and private partnerships, while, water governance in Bangladesh is found to be rather poor as the country has centralized system with lower public participation [3]. More complex and diverse governance regimes, in particular polycentric approach where power is distributed, can promote flexible decision making and adaptive management [63]. Engle et al. [6] demonstrate the Paraíba do Sul River basin of Brazil as an example, in which layered and polycentric institutional interactions fuelled by substantial social learning promote flexibility and adaptability in the decision making procedure.

\subsection{Developing “Intersectoral” or Multistakeholder Approaches}

IWRM recognises that stakeholders should be part of decision making process and water development and management should be based on a participatory approach, involving users, planners and policy-makers at all levels. In IWRM, multi-stakeholder approach is the best means for achieving long-lasting consensus and common agreement. Adequate water allocation can be agreed by stakeholders, using community based methods of water allocation for different sectors. Therefore, participatory mechanisms can improve the efficiency of water use and allow adequate supply of other resources in sustainable manner. Through community engagement, participatory approach makes flexible decisions at lowest appropriate level which provides an opportunity of social learning based on adaptive cycle [63]. However, participation does not always achieve consensus and it has to be recognised that simply creating participatory opportunities will do nothing for currently disadvantaged groups unless their capacity to participate is enhanced. Therefore, the benefits of participatory approaches vary among developed and developing nations.

\subsection{Ensuring Equity in Resource Access}

Water has a value as an economic good as well as a social good. Considering water as a social good, equity within IWRM ensures access to water and related resources among poor people. Consequently, IWRM extracts maximum benefits from available water through proper allocation of resources. Equity also ensures participation of marginal groups. Nevertheless, promoting equity in resource access helps ensure that stakeholders gain access to decision-making and to resources, thereby helping adaptive capacity. However, it does not promote flexible decision making and adaptive management.

\subsection{Demand Management}

Within IWRM, demand management achieves more desirable allocations and sustainable use of water through targeting the water user rather than the supply of water. Demand management strategies aims to influence users' demand in order to achieve efficiency and to promote equity and environmental integrity [64]. It has many instruments among which: quota, licence to use, tradable water right, user charges, subsidies, and penalties are important. Besides these implementation incentives, an important component of demand management is public participation through awareness raising, education, and training. However, demand management does not ensure adaptive cycle and flexible decision making.

\section{Conclusions}

The Integrated Water Resources Management (IWRM) approach is proposed for economically, socially and environmentally sustainable use of water and related resources that increases adaptive capacity of the water resources system (WRS). In this study, we examine the features of IWRM regarding their contribution towards increasing the adaptive capacity to climate change impact. The results demonstrate that all the key dimensions of IWRM promote adequate supply of resources and facilitate participatory mechanisms, which can enhance adaptive capacity. Despite IWRM being promoted as an attractive approach for increasing adaptive capacity, our assessment depicts that IWRM can not enhance flexibility and adaptability. Adaptability increases the capability of a system to adjust, via changes in its characteristics or behavior; so as to cope better with existing and future stresses [65]. Due to climate change impact, these stresses are expected to further increase on water resources system (WRS). Therefore, the consequences of climate change i.e., uncertainty and extreme events, on WRS underline the importance of flexibility and adaptability.

Similar to Pahl-Wostl [65], this study suggests that there is a need for a change in current water management practices towards more adaptive and flexible approaches. Greater integration of such adaptive and flexible approaches into IWRM approaches worldwide are urgently needed to tackle the complexities and uncertainties related to a changing climate and enable the sustainable use and management of water resources.

\section{Acknowledgements}

The authors are grateful to European Science Foundation for facilitating this interdisciplinary research work.

\section{REFERENCES}

[1] A. K. Gain, C. Giupponi and F. Renaud, "Climate Change Adaptation and Vulnerability Assessment of Water Resources Systems in Developing Countries: A Generalized Framework and a Feasibility Study in Bangladesh," Wa- 
ter, Vol. 4, No. 2, 2012, pp. 345-366.

[2] J. B. Agyenim and J. Gupta, "IWRM and Developing Countries: Implementation Challenges in Ghana," Physics and Chemistry of the Earth, Vol. 47-48, 2012, pp. 46-57. doi:10.1016/j.pce.2011.06.007

[3] A. K. Gain and M. Schwab, "An Assessment of Water Governance Trends: The Case of Bangladesh," Water Policy, Vol. 14, No. 5, 2012, pp. 821-840. doi:10.2166/wp.2012.143

[4] Z. W. Kundzewicz, L. J. Mata, N. W. Arnell, P. Döll, P. Kabat, B. Jiménez, K. A. Miller, T. Oki, Z. Sen and I. A. Shiklomanov, "Freshwater Resources and Their Management," In: M. L. Parry, O. F. Canziani, J. P. Palutikof, P. J. van der Linden and C. E. Hanson, Eds., Climate Change 2007: Impacts, Adaptation and Vulnerability. Contribution of Working Group II to the Fourth Assessment Report of the Intergovernmental Panel on Climate Change, Cambridge University Press, Cambridge, 2007, pp. 173-210.

[5] W. Medema, B. S. McIntosh and P. J. Jeffrey, "From Premise to Practice: A Critical Assessment of Integrated Water Resources Management and Adaptive Management Approaches in the Water Sector," Ecology and Society, Vol. 13, No. 2, 2008, Article 29.

http://www.ecologyandsociety.org/vol13/iss2/art29/

[6] N. L. Engle, O. R. Johns, M. Lemos and D. R. Nelson, "Integrated and Adaptive Management of Water Resources: Tensions, Legacies, and the Next Best Thing," Ecology and Society, Vol. 16, No. 1, 2011, Article 19. http://www.ecologyandsociety.org/vol16/iss1/art19/

[7] D. Huitema, E. Mostert, W. Egas, S. Moellenkamp, C. Pahl-Wostl and R. Yalcin, "Adaptive Water Governance: Assessing the Institutional Prescriptions of Adaptive (Co)management from a Governance Perspective and Defining a Research Agenda," Ecology and Society, Vol. 14, No. 1, 2009, Article 26.

http://www.ecologyandsociety.org/vol14/iss1/art26/

[8] N. L. Engle, "Adaptive Capacity and Its Assessment," Global Environmental Change, Vol. 21, No. 2, 2011, pp 647-656. doi:10.1016/j.gloenvcha.2011.01.019

[9] F. Miller, H. Osbahr, E. Boyd, F. Thomalla, S. Bharwani, G. Ziervogel, B. Walker, J. Birkmann, S. van der Leeuw, J. Rockström, J. Hinkel, T. Downing, C. Folke and D. Nelson, "Resilience and Vulnerability: Complementarity or Conflicting Concepts," Ecology and Society, Vol. 15, No. 3, 2010, Article 11.

http://www.ecologyandsociety.org/vol15/iss3/art11/

[10] G. Sartori, "Concept Misinformation in Comparative Politics," American Political Science Review, Vol. 64, No. 4, 1970, pp. 1033-1053.

http://www.jstor.org/stable/1958356 doi: $10.2307 / 1958356$

[11] O. Fritsch and D. Benson, "Integrating the Principles of IWRM? River Basin Planning in England and Wales," International Journal of Water Governance, 2013, in press.

[12] F. Molle, "River-Basin Planning and Management: The Social Life of a Concept," Geoforum, Vol. 40, 2009, pp. 484-494. doi:10.1016/j.geoforum.2009.03.004

[13] A. K. Gerlak, "Federalism and US Water Policy: Lessons for the Twenty-First Century," Publius, Vol. 36, No. 2, 2006, pp. 231-257. doi:10.1093/publius/pji032

[14] P. A. Sabatier, C. Weible and J. Ficker, "Eras of Water Management in the United States: Implications for Collaborative Watershed Approaches," In: P. A. Sabatier, W. Focht, M. Lubell, Z. Trachtenberg, A. Vedlitz and M. Matlock, Eds., Swimming Upstream: Collaborative Approaches to Watershed Management, MIT Press, Cambridge, 2005, pp. 23-52.

[15] R. N. L. Andrews, "Managing the Environment, Managing Ourselves," Yale University Press, New Haven, 2006.

[16] H. Cook, "The Protection and Conservation of Water Resources: A British Perspective," John Wiley \& Sons Ltd., London, 1998.

[17] L. Robins, "Major Paradigm Shifts in NRM in Australia," International Journal of Global Environmental Issues, Vol. 7, No. 4, 2007, pp. 300-311. doi:10.1504/IJGENVI.2007.016110

[18] D. Benson and A. Jordan, "Understanding Task Allocation in the European Union: Exploring the Value of Federal Theory," Journal of European Public Policy, Vol. 15, No. 1, 2008, pp. 78-97. doi:10.1080/13501760701702215

[19] H. H. G. Savenije and P. Van der Zaag, "Integrated Water Resources Management: Concepts and Issues," Physics and Chemistry of the Earth, Vol. 33, No. 5, 2008, pp. 290-297. doi:10.1016/j.pce.2008.02.003

[20] A. K. Biswas, "Current Directions: Integrated Water Resources Management-A Second Look," Water International, Vol. 33, No. 3, 2008, pp. 274-278. doi: $10.1080 / 02508060802272812$

[21] World Commission on Environment and Development (WCED), "Our Common Future," Oxford University Press, Oxford, 1987.

[22] L. De Stefano, "International Initiatives for Water Policy Assessment: A Review," Water Resources Management, Vol. 24, No. 11, 2010, pp. 2449-2466. doi:10.1007/s11269-009-9562-7

[23] D. Benson, A. Jordan and D. Huitema, "Involving the public in Catchment Management: An Analysis of the Scope for Learning Lessons from Abroad," Environmental Policy and Governance, Vol. 22, No. 1, 2012, pp. 42-54. doi:10.1002/eet.593

[24] M. M. Rahaman, O. Varis and T. Kajander, "EU Water Framework Directive vs. Integrated Water Resources Management: The Seven Mismatches," International Journal of Water Resources Development, Vol. 20, No. 4, 2004, pp. 565-575. doi:10.1080/07900620412331319199

[25] B. Mitchell, "IWRM in Practice: Lessons from Canadian Experiences," Journal of Contemporary Water Research \& Education, Vol. 135, No. 1, 2006, pp. 51-55. doi:10.1111/j.1936-704X.2006.mp135001006.x

[26] N. Funke, S. H. H. Oelofse, J. Hattingh, P. J. Ashton and A. R. Turton, "IWRM in Developing Countries: Lessons from the Mhlatuze Catchment in South Africa," Physics and Chemistry of the Earth, Parts A,B,C, Vol. 32, No. 15-18, 2007, pp. 1237-1245. doi:10.1016/j.pce.2007.07.018

[27] L. Horlemann and I. Dombrowsky, "Institutionalising 
IWRM in Developing and Transition Countries: The Case of Mongolia," Environmental Earth Sciences, Vol. 65, No. 5, 2012, pp. 1547-1559. doi:10.1007/s12665-011-1213-7

[28] I. Fischhendler, "Institutional Conditions for IWRM: The Israeli Case," Ground Water, Vol. 46, No. 1, 2008, pp. 91-102.

[29] W. O. Mulwafu and H. K. Msosa, "IWRM and Poverty Reduction in Malawi: A Socio-Economic Analysis," Physics and Chemistry of the Earth, Vol. 30, No. 11-16, 2005, pp. 961-967.

[30] F. P. Maganga, H. L. Kiwasila, I. H. Juma and J. A. Butterworth, "Implications of Customary Norms and Laws for Implementing IWRM: Findings from Pangani and Rufiji Basins, Tanzania," Physics and Chemistry of the Earth, Vol. 29, No. 15-18, 2004, pp. 1335-1342. doi:10.1016/j.pce.2004.09.008

[31] V. Sokolov, "Experiences with IWRM in the Central Asia and Caucasus Regions," Water International, Vol. 31, No. 1, 2006, pp. 59-70. doi:10.1080/02508060608691915

[32] P. Stålnacke and G. D. Gooch, "Integrated Water Resources Management," Irrigation and Drainage Systems, Vol. 24, No. 3-4, 2010, pp. 155-159. doi:10.1007/s10795-010-9106-6

[33] Global Water Partnership (GWP), "IWRM Components," GWP, Stockholm, 2012.

[34] J. A. Ballweber, "A Comparison of IWRM Frameworks: The United States and South Africa," Journal of Contemporary Water Research \& Education, Vol. 135, No. 1, 2006, pp. 74-79. doi:10.1111/j.1936-704X.2006.mp135001009.x

[35] E. Mostert, M. Craps and C. Pahl-Wostl, "Social Learning: The Key to Integrated Water Resources Management?" Water International, Vol. 33, No. 3, 2008, pp. 293-304. doi:10.1080/02508060802275757

[36] C. Pahl-Wostl and J. Sendzimir, "The Relationship between IWRM and Adaptive Management," NeWater Project, Osnabrück, 2005, NeWater Working Papers No. 3.

[37] United Nations (UN), "International Conference on Water and the Environment: Dublin Principles," UN, New York, 1992.

[38] J. Pierre and B. G. Peters, "Governance, Politics and the State," St. Martin's Press, New York, 2000.

[39] W. N. Adger and A. Jordan, "Governing Sustainability," Cambridge University Press, Cambridge, 2009. doi:10.1017/CBO9780511807756

[40] A. Jordan, D. Benson, R. K. W. Wurzel and A. R. Zito, "Environmental Policy: Governing by Multiple Policy Instruments?” In: J. Richardson, Ed., Constructing a Policy-Making State? Policy Dynamics in the European Union, Oxford University Press, Oxford, 2012, pp. 104-124. doi:10.1093/acprof:oso/9780199604104.003.0006

[41] M. Lockwood and J. Davidson, "Environmental Governance and the Hybrid Regime of Australian Natural Resource Management," Geoforum, Vol. 41, No. 3, 2010, pp. 388-398. doi:10.1016/j.geoforum.2009.12.001

[42] B. Smith, O. Pilifosova, I. Burton, B. Challenger, S. Huq, R. J. T. Klein, G. Yohe, N. Adger, T. Downing, E. Har- vey, S. Kane, M. Parry, M. Skinner, J. Smith and J. Wandel, "Adaptation to Climate Change in the Context of Sustainable Development and Equity," In: J. J. McCarthy, O. F. Canziani, N. A. Leary, D. J. Dokken and K. S. White, Eds., Climate Change 2001: Impacts, Adaptation and Vulnerability, Contribution of Working Group II to the Third Assessment Report of the Intergovernmental Panel on Climate Change, Cambridge University Press, Cambridge, 2001, pp. 877-912.

[43] G. Yohe and R. S. J. Tol, "Indicators for Social and Economic Coping Capacity-Moving towards a Working Definition of Adaptive Capacity," Global Environmental Change, Vol. 12, No. 1, 2002, pp. 25-40. doi:10.1016/S0959-3780(01)00026-7

[44] W. N. Adger, S. Agrawala, M. Q. Mirza, C. Conde, K. O'Brien, J. Pulhin, R. Pulwarty, B. Smit and K. Takahashi, "Assessment of Adaptation Practices, Options, Constraints and Capacity," In: M. L. Parry, O. F. Canziani, J. P. Palutikof, P. J. van der Linden and C. E. Hanson, Eds., Climate Change 2007: Impacts, Adaptation and Vulnerability, Contribution of Working Group II to the Fourth Assessment Report of the Intergovernmental Panel on Climate Change, Cambridge University Press, Cambridge, 2007, pp. 717-743.

[45] B. Smit and J. Wendel, "Adaptation, Adaptive Capacity and Vulnerability," Global Environmental Change, Vol. 16, No. 3, 2006, pp. 282-292. doi:10.1016/j.gloenvcha.2006.03.008

[46] C, Folke, T. Hahn, P. Olsson and J. Norberg, "Adaptive Governance of Social-Ecological Systems," Annual Review of Environment and Resources, Vol. 30, 2005, pp. 441-473. doi:10.1146/annurev.energy.30.050504.144511

[47] P. Olsson, C. Folke and F. Berkes, "Adaptive Comanagement for Building Resilience in Social-Ecological Systems," Environmental Management, Vol. 34, No. 1, 2004, pp. 75-90. doi:10.1007/s00267-003-0101-7

[48] S. Hatfield-Dodds, R. Nelson and D. C. Cook, "Adaptive Governance: An Introduction, and Implications for Public Policy," The ANZSEE Conference, Noosa, 5-7 July 2007.

[49] D. R. Nelson, W. N. Adger and K. Brown, "Adaptation to Environmental Change: Contributions of a Resilient Framework," Annual Review of Environmental Resources, Vol. 32, No. 1, 2007, pp. 395-419.

doi:10.1146/annurev.energy.32.051807.090348

[50] C. Folke, J. Colding and F. Berkes, "Synthesis: Building Resilience and Adaptive Capacity in Social-Ecological Systems," In: F. Berkes, J. Colding and C. Folke, Eds., Navigating Social-Ecological Systems: Building Resilience for Complexity and Change, Cambridge University Press, Cambridge, 2003, pp. 352-387.

[51] A. Duit, V. Galaz, K. Eckerberg and J. Ebbesson, "Governance, Complexity, and Resilience," Global Environmental Change, Vol. 20, No. 3, 2010, pp. 363-368. doi:10.1016/i.gloenvcha.2010.04.006

[52] D. Armitage, M. Marschke and R. Plummer, "Adaptive Co-Management and the Paradox of Learning," Global Environmental Change, Vol. 18, No. 1, 2008, pp. 86-98. doi:10.1016/j.gloenvcha.2007.07.002

[53] O. Young, "Vertical Interplay among Scale-Dependent 
Environmental and Resource Regimes," Ecology and Society, Vol. 11, No. 1, 2006, Article 27.

http://www.ecologyandsociety.org/vol11/iss1/art27/

[54] E. W. Dungumaro and N. F. Madulu, "Public Participation in Integrated Water Resources Management: The Case of Tanzania," Physics and Chemistry of the Earth, Parts A/B/C, Vol. 28, No. 20-27, 2003, pp. 1009-1014. doi:10.1016/j.pce.2003.08.042

[55] J. Warner, P. Wester and A. Bolding, "Going with the Flow: River Basins as the Natural Units for Water Management?" Water Policy, Vol. 10, No. S2, 2008, pp. 121138. doi:10.2166/wp.2008.210

[56] F. G. W. Jaspers, "Institutional Arrangements for Integrated River Basin,” Water Policy, Vol. 5, No. 1, 2003, pp. 77-90.

[57] J. Blatter and H. Ingram, "States, Markets and Beyond: Governance of Transboundary Water Resources," Natural Resources Journal, Vol. 40, No. 2, 2000, pp. 439-471.

[58] F. Molle, P. Wester and P. Hirsch, "River Basin Development and Management," In: D. Molden, Ed., Water for Food, Water for Life: A Comprehensive Assessment of Water Management in Agriculture, Earthscan, London, 2006, pp. 585-624.

[59] F. B. Van Cleve, T. Leschine, T. Klinger and C. Simenstad, "An Evaluation of the Influence of Natural Science in Regional-Scale Restoration Projects," Environmental Management, Vol. 37, No. 3, 2006, pp. 367-379.

\section{doi:10.1007/s00267-005-0014-8}

[60] H. Ingram and L. Fraser, "Path Dependency and Adroit Innovation: The Case of California Water," In: R. C. Repetto, Ed., Punctuated Equilibrium and the Dynamics of US Environmental Policy, Yale University Press, New Haven, 2006, pp. 78-109.

[61] A. K. Biswas and C. Tortajada, "Future Water Governance: Problems and Perspectives," International Journal of Water Resources Development, Vol. 26, No. 2, 2010, pp. 129-139. doi:10.1080/07900627.2010.488853

[62] W. Blomquist, A. Dinar and K. Kemper, "Comparison of Institutional Arrangements for River Basin Management in Eight Basins," World Bank, Washington DC, 2005, World Bank Policy Research Working Paper 3636.

[63] C. Pahl-Wostl, "A Conceptual Framework for Analyzing Adaptive Capacity and Multi-Level Learning Processes in Resource Governance Regime," Global Environmental Change, Vol. 19, No. 3, 2009, pp. 354-365. doi:10.1016/j.gloenvcha.2009.06.001

[64] H. Savenije and P. van der Zang, "Water as an Economic Good and Demand Management Paradigms with Pitfalls," Water International, Vol. 27, No. 1, 2002, pp. 98-104. doi: $10.1080 / 02508060208686982$

[65] C. Pahl-Wostl, "Transitions towards Adaptive Management of Water Facing Climate and Global Change," Water Resources Management, Vol. 21, No. 1, 2007, pp. 49-62. doi:10.1007/s11269-006-9040-4 